\title{
ANALISIS PENGARUH PERPUTARAN KREDIT TERHADAP \\ RENTABILITAS EKONOMI STUDI KASUS PADA KOPERASI REPUBLIK INDONESIA (KPRI) OBOR KOTA BIMA
}

\author{
Wahyuni \\ wahyunikawaii4478@gmail.com
}

\begin{abstract}
ABSTRAK
Jenis penelitian yang digunakan dalam penelitian ini adalah studi kasus yaitu penelitian yang dilakukan secara langsung untuk mendapatkan data yang lebih akurat dan hasil penelitian hanya berlaku untuk objek yang diteliti. Analisis data dalam penelitian ini menggunakan analisa dinamis yaitu penganalisaan antara pos-pos yang terdapat dalam laporan keuangan pada beberapa periode, atau yang lebih dikenal dengan analisa ratio koperasi dengan menggunakan analisa rasio perputaran kredit, rasio likuiditas, rasio rentabilitas dan rasiomodal atas aset dengan menggunakan pendekatan return on assets (ROA). Hasil analisa rasio menunjukkan bahwa rasio likuiditas (Curent ratio) setiap tahun mengalami fluktuasi yaitu tahun 2013 sebesar $133.86 \%$, tahun 2014 sebesar $102.88 \%$, tahun 2015 sebesar 98.92\%, tahun 2016 sebesar 105.99\%, dan tahun 2017 sebesar $101.44 \%$. sedangkan tingkat perputaran kredit atau receivable turn over (RTO) mengalami perputaran di atas seribu kali bahkan untuk tahun 2015 dan 2016 diatas duaribu kali yaitu masing-masing sebesar 2.107 dan 2.216. demikian juga dengan tingkat perputaran rentabilitas setiap tahunnya mengalami peningkatan yaitu berputar rata-rata diatas seribu kali dalam setahun.Dari hasil analisis ekonomi diatas dapat disimpulkan bahwa perputaran kredit memiliki pengaruh signifikan terhadap peningkatan Rentabilitas (ROA).
\end{abstract}

Kata Kunci: Perputaran Kredit, Rentabilitas

\section{PENDAHULUAN}

Koperasi Pegawai Repoblik Indonesia (KPRI) OBOR adalah koperasi guru-guru Pegawai Republik Indonesia di mana anggotanya adalah pegawaipegawai yang tersebar diseluruh wilayah Kota Bima dimana kegiatan usahanya adalah simpan pinjam dan usaha penjualan sembako. Untuk meningkatkan kesejahteraan anggota maka Koperasi Pegawai repoblik Indonesia (KPRI) OBOR harus berperan serta dalam mewujudkan setiap harapan yang diinginkan oleh anggota salah satunya adalah pemberian kredit pinjaman dengan bunga yang ringan. Dengan penyalutan kredit yang mudah dan bunga pinjaman yang murah diharapkan mampu untuk meningkatkan perputaran rentabilitas koperasi itu sendiri.

Suatu badan usaha dalam hal ini adalah koperasi, tentunya mengharapkan laba yang optimal, sesuai dengan kemampuan dalam menggunakan modalnya karena kesejahteraan akan meningkat seiring dari kemajuan koperasi. Namun menurut Riyanto (2001:37), bagi perusahaan 117 | Program Studi Pendidikan Ekonomi, Sekolah Tinggi Keguruan dan Ilmu Pendidikan (STKIP) Bima 


\section{"Jurnal PenKoMi : Kajian Pendidikan dan \\ Ekonomi" STKIP Bima Vol. 2, No. 1 Januari 2019 e-ISSN: 2614-6002}

pada umumnya, masalah rentabilitas adalah lebih penting dari pada laba, karena laba yang besar belum merupakan ukuran bahwa koperasi tersebut telah bekerja dengan efisien.Rentabilitas merupakan kriteria yang paling valid sebagai alat pengukur hasil pelaksanaan operasi perusahaan (Harnanto, 1991:352).Dengan demikian yang harus diperhatikan oleh koperasi adalah tidak hanya usaha untuk memperbesar laba, tetapi yang lebih penting adalah usaha untuk mempertinggi rentabilitasnya. Rentabilitas dapat diketahui dengan membandingkan antara laba dengan kekayaan dan modal yang dikeluarkan untuk mendapatkan laba tersebut (Riyanto,2001:31).

Dalam Undang-Undang Nomor. 25 Tahun 1992 pasal 1 (1) disebutkan bahwa "Koperasi adalah badan usaha yang beranggotakan orang seorang atau badan hokum koperasi dengan melandaskan kegiatannya berdasarkan prinsip koperasi sekaligus sebagai gerakan ekonomi rakyat yang berdasarkan atas asas kekeluargaan (UU Koperasi, 1992:6).

Sedangkan ahli lain berpendapat, Koperasi adalah kumpulan orang-orang sebagai manusia yang secara bersama-sama bergotong royong berdasarkan persamaan, bekerja untuk memajukan kepentingan-kepentingan ekonomi mereka akan kepentingan masyarakat (Hasan,1996:137).

Dari pendapat diatas dapat disimpulkan bahwa koperasi adalah kumpulan orang-orang ataubadan hukum koperasi yang secara bersama-sama bekerja memperjuangkan kesejahteraan anggota pada khususnya dan masyarakat pada umumnya serta koperasi harus memanfaatkan peluang dan kesempatan yang ada dalam upaya meningkatkan kesejahteraan anggota tersebut.

Menurut Sudarsono dan Edilius (2005 : 80) koperasi Indonesia sebagai salah satu alat untuk membangun ekonomi rakyat bukan mengejar semata-mata keuntungan tetapi yang utama memberikan jasa para anggota, bersemangat dan bergairah bekerja sehingga tercapai peningkatan pendapatan, jadi fungsi koperasi terdiri dari:

a. Alat perjuangan ekonomi

b. Alat pendemokrasian Nasional

c. Sebagai salah satu urat nadi perekonomian Indonesia

d. Sebagai alat pembinaan insan masyarakat untuk memperkokoh kedudukan ekonomi bangsa Indonesia serta bersatu dalam mengatur tatalaksana perekonomian rakyat.

Dalam Undang-Undang Nomor 25 tentang perkoperasian Tahun 1992 pasal 3 disebutkan bahwa "koperasi bertujuan memajukan kesejahteraan anggota pada khususnya dan masyarakat pada umumnya serta ikut membangun tatanan perekonomian nasional dalam rangka mewujudkan masyarakat yang maju, adil dan makmur berlandaskan pancasila dan Undang-Undang dasar 1945.

Tujuan ekonomi yang berada dalam koperasi yakni bekerjasama berdasarkan motif ekonomi dan mencari keuntungan dalam bagian-bagian yang saling berkaitan. Tujuan tidak semata-mata mencari keuntungan tetapi meningkatkan kesejahteraan anggota, memberi kemudahan dan menyediakan fasilitas untuk memuaskan kebutuhan para anggota. Memberi bimbingan dan

\section{I8 | Program Studi Pendidikan Ekonomi, Sekolah Tinggi Keguruan dan Ilmu Pendidikan (STKIP) Bima}




\section{"Jurnal PenKoMi : Kajian Pendidikan dan Ekonomi" STKIP Bima Vol. 2, No. 1 Januari 2019

pembinaan kepada para anggotanya agar mereka dapat memperbaiki kinerja dan prestasi, jumlah hasil kerja sehingga dalam wadah koperasi tercipta secara terpadu dan terorganisir (Tasrif, 2008:198).

Dengan kesejateraan anggota akan membawa dampak terhadap perekonomian nasional, sehingga sangat tepat apabila koperasi juga ikut andil dalam membangun tatanan perekonomian nasional dalam rangka mewujudkan masyarakat yang maju dalam arti dapat mengikuti perkembangan jaman, ilmu pengetahuan dan teknologi, serta ikut mewujudkan masyarakat yang adil, makmur berdasarkan pancasila dan Undang-Undang Dasar 1945.

Jadi dari uraian di atas bahwa tujuan yang utama dan terdekat untuk dicapai oleh koperasi adalah meningkatkan taraf dan kesejahteraan hidup anggotaanggotanya.

\section{Perputaran Kredit}

Menurut Munawir (1995:75) makin tinggi perputaran kredit (turn over) Menunjukan modal kerja yang ditanamkan dalam piutang rendah. Sebaliknya kalau rasio semakin rendah berati ada over investment dalam piutang sehingga memerlukan analisa lebih lanjut, mungkin karena bagian kredit dan penagihan tidak bekerja efektif atau mungkin adfa perubahan dalam proses pemberian kredit. Semakin cepat perputaran piutang menunjukan modal dapat digunakan secara efisien.

Rasio perputaran kredit diperlukan untuk mengetahui perbandingan kredit yang diberikan untuk setiap tahunnya dan bagaimana perputaran kredit yang terjadi.

Untuk menganalisis perputaran kredit digunakan rumus(Santoso,1996:10:4) :

$$
\begin{gathered}
R T O=\frac{\text { kredit yang diberikan selama setahun }}{\text { rata }- \text { rata kredit }} \\
\text { Ratarata kredit }=\frac{\text { kredit awal tahun }+ \text { kredit akhir tahun }}{2}
\end{gathered}
$$

\section{Rentabilitas}

Rentabilitas adalah kemampuan perusahaan untuk menghasilkan laba dengan modal yang dimiliki oleh perusahaan untuk periode tertentu. Rentabilitas merupakan kriteria yang paling valid sebagai alat pengukur hasil operasi pelaksanaan perusahaan (Harnanto,1992:352). Adapun cara untuk menilai suatu rentabilitas adalah dengan membandingkan antara laba dan aktiva.

Fungsi rentabilitas adalah untuk menilai hasil operasi perusahaan (Harnanto,1991:352):

1. Indikator efektivitas manajemen

Tinggi rendahnya rentabilitas perusahaan tergantung tergantung usaha dan motivasi manajemen.

2. Suatu alat untuk memproyeksi laba perusahaan.

Rentabilitas dapat digunakan sebagai alat untuk memproyeksi laba perusahaan karena rentabilitas menggambarkan korelasi antara laba dengan modal yang 


\section{"Jurnal PenKoMi : Kajian Pendidikan dan Ekonomi" STKIP Bima Vol. 2, No. 1 Januari 2019}

ditanamkan sehingga membantu analis memproyeksikan laba pada perubahan modal.

3. Suatu alat pengendalian manajemen

Bagi pihak intern manajemen, likuiditas dapat dipakai sebaga alat pengendali.Rentabilitas dapat dipakai sebagai alat penyusunan budget, koordinasi, evaluasi hasil pelaksanaan operasi perusahaan kriteria penilaian alternatif dan dasar pengendalian penanaman modal.

Rentabilitas merupakan pencerminan dari hasil usaha yang sebagian besar diperoleh dari operasional bagian perkreditan khususnyapenerimaan bunga. Apabila penerimaan bunga mengalami penundaan atau bahkan tidak tertagih, maka penilaian atas rasio laba terhadap total aset akan rendah.

\section{METODE PENELITIAN}

Jenis penelitian yang digunakan dalam penelitian ini adalah studi kasus yaitu penelitian yang dilakukan secara langsung untuk mendapatkan data yang lebih akurat dan hasil penelitian hanya berlaku untuk objek yang diteliti (Notoatmodjo, 2010:47).Adapun yang menjadi subyek dalam penelitian ini adalah pengurus, pengawas, anggota dan karyawan pada koperasi Koperasi pegawai Repoblik Indonesia (KPRI) Obor Bima untuk di wawancarai mengenai data yang dibutuhkan.Sedangkan objek penelitian adalah tingkat perputaran kredit dan rentabilitas ekonomi pada koperasi Koperasi pegawai Repoblik Indonesia (KPRI) Obor Bima.

Metode analisis data adalah merupakan tata cara yang harus diikuti atau digunakan oleh peneliti dalam rangka menganalisasi data yang sudah di simpulkan. Sesuai dengan jenis penelitian yang telah diutarakan, maka analisis data penelitian ini menggunakan analisa dinamis yaitu penganalisaan antara pospos yang terdapat dalam laporan keuangan pada beberapa periode, atau yang lebih dikenal dengan analisa ratio koperasi dengan menggunakan analisa rasio perputaran kredit dan rasio rentabilitas ekonomi.

\section{HASIL PENELITIAN DAN PEMBAHASAN}

\section{A. Hasil Penelitian}

Adapun data mengenai laporan keuangan modal kerja dan current ratio terhadap Rentabilitas ( ROA) pada KPRI Obor Guru-Guru Kota Bima periode 20013-2017 dapat dilihat sebagai berikut:

Tabel 1 perkembangan Modal usaha, Current Ratio koperasi KPRI "Obor" Guru-guru Kota bima dari tahun 2013 sampai dengan 2017

\begin{tabular}{|c|c|c|c|c|}
\hline Tahun & $\begin{array}{c}\text { Aktiva Lancar } \\
(\mathrm{Rp})\end{array}$ & $\begin{array}{c}\text { Hutang Lancar } \\
(\mathrm{Rp})\end{array}$ & $\begin{array}{c}\text { Modal Kerja } \\
\text { (Aktiva lancar- } \\
\text { Hutang lancar } \\
(\mathrm{Rp})\end{array}$ & $\begin{array}{c}\text { Rasio } \\
\text { likuiditas } \\
\text { (Current } \\
\text { Ratio) }\end{array}$ \\
\hline 2013 & $10.155 .540 .834,56$ & $758.666 .278,25$ & $9.396 .874 .556,31$ & $133.86 \%$ \\
\hline 2014 & $11.372 .444 .177,40$ & $1.105 .354 .307,43$ & $10.267 .089 .869,97$ & $102.88 \%$ \\
\hline 2015 & $11.437 .921 .114,18$ & $1.156 .202 .615,21$ & $10.281 .718 .498,97$ & $98.92 \%$ \\
\hline 2016 & $12.676 .106 .473,37$ & $1.195 .896 .472,56$ & $11.480 .210 .000,81$ & $105.99 \%$ \\
\hline 2017 & $12.612 .400 .041,78$ & $1.243 .236 .728,61$ & $11.369 .163 .313,17$ & $101.44 \%$ \\
\hline
\end{tabular}

\section{0 | Program Studi Pendidikan Ekonomi, Sekolah Tinggi Keguruan dan Ilmu Pendidikan (STKIP)} Bima 


\section{"Jurnal PenKoMi : Kajian Pendidikan dan Ekonomi" STKIP Bima Vol. 2, No. 1 Januari 2019 e-ISSN: 2614-6002}

Berdasarkan tabel di atas dapat dilihat bahwa tingkat modal kerja yang dimiliki perusahaan terus berfluktuasi dari tahun 2013 sampai tahun 2017.

Selanjutnya untuk mengetahui perkembangan modal sendiri dan total aktiva dalam lima tahun terakhir yaitu tahun 2013 sampai dengan tahun 2017 dan juga untuk mengetahui tingkat kesehatan koperasi dari aspek permodalan dengan rumus sebagai berikut:

Modal Sendiri x $100 \%$

Total Aktiva

Adapun informasi secara lengkap bisa dilihat pada tabel 4.2 dibawah ini.

Tabel 2 perkembangan Modal sendiri (Equity) dan total aktiva koperasi KPRI "Obor" Guru-guru Kota bima dari tahun 2013 sampai dengan 2017

\begin{tabular}{|c|c|c|c|}
\hline Tahun & $\begin{array}{c}\text { Modal sendiri } \\
(\mathrm{Rp})\end{array}$ & $\begin{array}{c}\text { Total Aktiva } \\
(\mathrm{Rp})\end{array}$ & Ratio \\
\hline 2013 & $6.429 .679 .962,31$ & 10.530 .335 .281 .56 & $61.05 \%$ \\
\hline 2014 & $7.471 .845 .421,31$ & 11.726 .806 .832 .40 & $63.71 \%$ \\
\hline 2015 & $8.133 .141 .886,31$ & $11.787 .598 .222,18$ & $68,99 \%$ \\
\hline 2016 & $9.040 .313 .024,81$ & $13.050 .928 .201,37$ & $70 \%$ \\
\hline 2017 & $9.801 .250 .599,17$ & $12.982 .967 .677,78$ & $75.49 \%$ \\
\hline
\end{tabular}

Sumber data: dokumen KPRI obor Bima.

Berdasarkan informasi yang ditunjukkan oleh tabel diatas dapat dijelaskan bahwa perkembangan modal sendiri dari tahun 2013 sampai dengan tahun 2017 mengalami fluktuasi dan terus meningkat. Dari informasi yang ditunjukkan oleh tabel diatas dapat dijelaskan bahwa modal sendiri pada tahun 2013 sebesar Rp. 6.429.679.962,31 dengan total aktiva sebesar Rp. 10.530.335.281.56 dan rasio modal sebesar 61.05\%. tahun 2014 dengan jumlah modal sendiri sebesar Rp. 7.471.845.421,31 dengan total aktiva sebesar Rp. 11.726.806.832.40 dan rasio modal sebesar 63.71\%. tahun 2015 dengan jumlah modal sendiri sebesar Rp. 8.133.141.886,31 dengan total aktiva sebesar Rp. 11.787.598.222,18 dan rasio modal sebesar 68,99\%. Tahun 2016 dengan jumlah modal sendiri sebesar Rp. 9.040.313.024,81 dengan total aktiva sebesar Rp. 13.050.928.201,37 dan rasio modal sebesar 70\%. Dan rasio modal paling tinggi adalah pada tahun 2017 yaitu sebesar 75.49\% dengan jumlah modal sendiri sebesar Rp. 9.801.250.599,17 dan total aktiva sebesar Rp. 12.982.967.677,78.

Selanjutnya untuk mengetahui tingkat perputaran kredit pada KPRI Obor tahun 2013 sampai dengan tahun 2017 dapat dilihat pada tabel 3 dibawah ini:

Tabel 3. Tingkat Perputaran Kredit mulai tahun 2013 Sampai dengan 2017

\begin{tabular}{|l|l|l|l|l|l|l|}
\hline Tahun & $\begin{array}{l}\text { Kredit Awal } \\
\text { Tahun (Rp) }\end{array}$ & $\begin{array}{l}\text { Kredit Akhir } \\
\text { tahun (Rp) }\end{array}$ & $\begin{array}{l}\text { Kredit setahun } \\
\text { (Rp) }\end{array}$ & $\begin{array}{l}\text { Rata-rata kredit } \\
\text { (Rp) }\end{array}$ & $\begin{array}{l}\text { Receivable } \\
\text { Turn over } \\
\text { ((RTO) }\end{array}$ \\
\hline 2013 & $4.435 .334 .361,00$ & $4.660 .804 .627,00$ & $9.405 .898 .628,56$ & 4.548 .069 .494 & 1.861 \\
\hline 2014 & $4.660 .804 .627,00$ & $4.978 .879 .873,00$ & $6.739 .775 .279,00$ & 4.819 .842 .250 & 1.398 \\
\hline 2015 & $4.978 .879 .873,00$ & $4.911 .900 .882,00$ & $10.420 .896 .416,58$ & 4.945 .390 .378 & 2.107 \\
\hline 2016 & $4.911 .900 .882,00$ & $5.073 .918 .063,00$ & $11.065 .695 .118,18$ & 4.992 .909 .473 & 2.216 \\
\hline 2017 & $5.073 .918 .063,00$ & $6.647 .829 .741,00$ & $10.909 .360 .510,00$ & 5.860 .873 .902 & 1.862 \\
\hline
\end{tabular}

Sumber data: penjelasan Neraca KPRI obor tahun 2013-2017

121 | Pragram Studi Pendidikan Ekanomi, Sekolah Tinggi Keguruan dan Ilmu Pendidikan (STKIP) Bima 


\section{"Jurnal PenKoMi : Kajian Pendidikan dan Ekonomi" STKIP Bima Vol. 2, No. 1 Januari 2019}

Selanjutnya untuk mengetahui tingkat rentabilitas ekonomi dengan membandingkan jumlah sisa hasil usaha sebelum dibagi (SHU) dengan total aktiva sesuai dengan rumus dibawah ini:

ROA $=\underline{\text { Jumlah SHU sebelum dibagi }} \times 100 \%$

Total Aktiva

Perhitungan lengkap mengenai rentabilitas ekonomi periode tahun 2013 sampai dengan tahun 2017 dapat dilihat pada tabel 4 dibawah ini:

Tabel 4 Tingkat Rentabilitas Ekonomi tahun 2013 sampai dengan tahun 2017

\begin{tabular}{|c|c|c|c|}
\hline Tahun & SHU (Rp) & Total aktiva (Rp) & $\begin{array}{c}\text { Return on } \\
\text { total assets } \\
\text { (ROA) }(\%)\end{array}$ \\
\hline 2013 & $1.411 .431 .874,58$ & $10.530 .335 .281,56$ & 1.340 \\
\hline 2014 & $1.836 .400 .000,00$ & $11.726 .806 .832,40$ & 1.566 \\
\hline 2015 & 1.755 .476 .796 .00 & $11.787 .598 .222,18$ & 1.489 \\
\hline 2016 & $1.680 .571 .527,75$ & $13.050 .928 .201,37$ & 1.288 \\
\hline 2017 & 1.851 .959 .429 .00 & $12.982 .967 .677,78$ & 1.426 \\
\hline
\end{tabular}

Sumber data: dokumen KPRI obor Bima

Dari informasi yang ditunjukkan pda tabel 4 diatas dapat dijelaskan bahwa tingkat perputaran rentabilitas selama tahun 2013 sampai dengan tahun 2017 terus mengalami fluktuasi. Pada tahun 2013 sisa hasil usaha yang diperoleh adalah sebesar Rp. 1.411.431.874,58 dengan total aktiva sebabnyak Rp. 10.530.335.281,56,- dan return on assets (ROA) sebesar $1.340 \%$. tahun 2014 sisa hasil usaha yang diperoleh meningkat dari tahun sebelumnya yaitu sebesar Rp. 1.836.400.000,00 dan juga total aktiva pun meningkat sebesar Rp. 11.726.806.832,40 sehingga return on assets ( ROA) yang diperoleh juga meningkat sebesar $1.566 \%$. tahun 2015 return on assets (ROA) menurun dibandingkan dengan tahun sebelumnya yaitu sebesar 1.489. hal ini disebabkan karena penurunan sisa hasil usaha yang diperoleh pada tahun ini menurun yaitu sebesar Rp. 1.755.476.796.00,-. Total aktiva yang paling tinggi adalah pada tahun 2016 yaitu sebesar Rp. 13.050.928.201,37,- tetapi ttetapi tidak diiringi oleh kenaikan jumlah sisa hasil usaha yang diterima malah pada tahun ini menurun yaitu sebesar Rp. 1.680.571.527,75,- oleh karena itu return on assets (ROA) pun menurun yaitu sebesar 1.288. artinya tingginya jumlah aktiva bukanlah sebuah jaminan untuk memperoleh sisa hasil usaha yang maksimal. Pada tahun 2017 total aktiva menurun dari tahun sebelumnya yaitu sebesar Rp. 12.982.967.677,78 tetapi memperoleh sisa hasil usaha yang paling tinggi dibandingkan dengan tahuntahun sebelumnya dengan perolehan return on assets (ROA) sebesar 1.426

\section{Pembahasan}

Berdasarkan hasil penelitian tentang Analisis Pengaruh Perputaran Kredit Terhadap Rentabilitas Ekonomi (Studi Kasus Pada Koperasi Pegawai Repoblik Indonesia (KPRI) Obor Kota Bima dapat diketahui bahwa bahwa rata-rata perputaran kredit dalam setahun seperti yang terlihat pada tabel receivable turn

122 | Program Studi Pendidikan Ekonomi, Sekolah Tinggi Keguruan dan Ilmu Pendidikan (STKIP) Bima 


\section{"Jurnal PenKoMi : Kajian Pendidikan dan \\ Ekonomi" STKIP Bima Vol. 2, No. 1 Januari 2019 e-ISSN: 2614-6002}

over (RTO) mengalami perputaran di atas seribu kali. Pada tahun 2013 perputaran kredit sebanyak 1.861 kali dalam setahun dengan jumlah kredit yang diberikan dalam setahun sebesar Rp. 9.405.898.628,56. Begitupun pada tahun 2014 sebanyak 1.398 kali dengan jumlah kredit dalam setahun sebesar Rp. 6.739.775.279,00. Perputaran kredit paling tinggi adalah terjadi pada tahun 2016 yaitusebanyak 2.216 kali. Hal inidisebabkan karena jumlah kredit yang dicairkan pada tahun ini paling tinggi diantara tahun-tahun sebelum dan sesudahnya yaitu sebesar Rp. 11.065.695.118,18.

Tingkat modal kerja yang dimiliki perusahaan terus berfluktuasi dari tahun 2013 sampai tahun 2017. Pada tahun 2013 posisi modal kerja koperasi sedikit berbeda dengan tahun-tahun yang lainnya yaitu di bawah 10 milyar tetapi apabila dilihat dari sudut rasio likuiditas dalam hal ini di analisis dengan menggunakan curent ratio tahun 2013 adalah posisi tertinggi rasio likuiditasnya yaitu sebesar $133.86 \%$ hal ini disebabkan hutang lancar pada tahun 2013 mengalami penurunan dibandingkan dengan tahun yang lain yaitu hanya sebesar Rp. 758.666.278,25. Interprestasi yang diperoleh dari analisa rasio likuiditas ini adalah setiap Rp.1 hutang lancar dijaminkan oleh Rp.13,38 atau 133,86\% jadi sangat likuid.

Demikian juga perkembangan modal sendiri dari tahun 2013 sampai dengan tahun 2017 mengalami fluktuasi dan terus meningkat. Dari informasi yang ditunjukkan oleh tabel diatas dapat dijelaskan bahwa modal sendiri pada tahun 2013 sebesar Rp. 6.429.679.962,31 dengan total aktiva sebesar Rp. 10.530.335.281.56 dan rasio modal sebesar 61.05\%. tahun 2014 dengan jumlah modal sendiri sebesar Rp. 7.471.845.421,31 dengan total aktiva sebesar Rp. 11.726.806.832.40 dan rasio modal sebesar 63.71\%. tahun 2015 dengan jumlah modal sendiri sebesar Rp. 8.133.141.886,31 dengan total aktiva sebesar Rp. 11.787.598.222,18 dan rasio modal sebesar 68,99\%. Tahun 2016 dengan jumlah modal sendiri sebesar Rp. 9.040.313.024,81 dengan total aktiva sebesar Rp. 13.050.928.201,37 dan rasio modal sebesar 70\%. Dan rasio modal paling tinggi adalah pada tahun 2017 yaitu sebesar $75.49 \%$ dengan jumlah modal sendiri sebesar Rp. 9.801.250.599,17 dan total aktiva sebesar Rp. 12.982.967.677,78.

Tingkat perputaran rentabilitas selama tahun 2013 sampai dengan tahun 2017 terus mengalami fluktuasi. Pada tahun 2013 sisa hasil usaha yang diperoleh adalah sebesar Rp. 1.411.431.874,58 dengan total aktiva sebabnyak Rp. 10.530.335.281,56,- dan return on assets (ROA) sebesar $1.340 \%$. tahun 2014sisa hasil usaha yang diperoleh meningkat dari tahun sebelumnya yaitu sebesar Rp. 1.836.400.000,00 dan juga total aktiva pun meningkat sebesar Rp. 11.726.806.832,40 sehingga return on assets ( ROA) yang diperoleh juga meningkat sebesar 1.566\%. tahun 2015 return on assets (ROA) menurun dibandingkan dengan tahun sebelumnya yaitu sebesar 1.489. hal ini disebabkan karena penurunan sisa hasil usaha yang diperoleh pada tahun ini menurun yaitu sebesar Rp. 1.755.476.796.00,-. sebelumnya dengan perolehan return on assets (ROA) sebesar 1.426 .

Dari hasil pengujian diatas dapat disimpulkan bahwa tingkat perputaran kredit cenderung menagalami peningkatan setiap tahunnya. Demikian juga tingkat perputaran kredit dapat mempengaruhi tingkat perputaran rentabilitas koperasi seperti yang ditunjukan pada hasil analisis diatas.

\section{3 | Program Studi Pendidikan Ekonomi, Sekolah Tinggi Keguruan dan Ilmu Pendidikan (STKIP) Bima}




\section{"Jurnal PenKoMi : Kajian Pendidikan dan}

Ekonomi" STKIP Bima Vol. 2, No. 1 Januari 2019

\section{KESIMPULAN}

Berdasarkan uraian-uraian yang telah penulis paparkan terhadap data penelitian yang telah terkumpul kemudian diolah mengenai Analisis Pengaruh Perputaran Kredit Terhadap Rentabilitas Ekonomi (Studi Kasus Pada Koperasi Pegawai Repoblik Indonesia (KPRI) Obor Kota Bima dapat diketahui bahwa:

1. Tingkat perputaran rentabilitas selama tahun 2013 sampai dengan tahun 2017 terus mengalami peningkatan yang signifikan yaitu diatas $100 \%$ kecuali Pada tahun 2015 yaitu sebesar $98.92 \%$

2. Tingkat perputaran kredit mengalami peningkatan setiap tahunnya yaitu mulai tahun 2013 sampai dengan tahun 2017 bahwa rata-rata perputaran kredit dalam setahun seperti yang dianalisis dengan menggunakan rumus receivable turn over (RTO) mengalami perputaran di atas seribu kali.

\section{DAFTAR RUJUKAN}

Arikunto, S. 1997. Prosedur Penelitian Suatu Pendekatan Praktek. Jakarta: Rineka Cipta

Anoraga, Panji dan Ninik Widiyanti. 1992. Dinamika Koperasi. Jakarta: Rineka Cipta

Harnanto. 1991. Analisa Laporan Keuangan. Yogyakarta: BPFE

Munawir. 2002. Analisa Laporan Keuangan. Edisi Eempat, Cetakan Kesepuluh, Yogyakarta:Penerbit LibertyYogyakarta.

Riyanto, Bambang. 2001. Dasar-dasar pembelanjaan Perusahaan. Jakarta: Bina Aksara

Santoso T. Rudi. 1996. Kredit usaha Perbankan. Yogyakarta: Andi

Siamat, Dahlan. 1993. Manajemen Lembaga Keuangan. Jakarta: Intermedia

Sudarsono dan Edilius.2005Analisis Laporan Keuangan.Jakarta : PT Bumi Aksara.

Suyatno, Tomas.1992. Dasar-dasar Perkreditan. Jakarta: PT Gramedia

Tunggal, Amin Wijaya. 1995. Akuntansi untuk Koperasi. Jakarta: Rineka Cipta

UU RI No. 25/1992 tentang Perkoperasian. Semarang: Aneka Ilmu

Wirasamita,Rivai dan Kenangasari,Ani,1990. Analisa Laporan keuangan Koperasi. Bandung: Pionir jaya. 